\title{
АНАЛІТИЧНА ФІЛОСОФІЯ
}

https://doi.org/10.15407/fd2021.04.142

УДК 165

Наталія ВЯТКІНА, кандидатка філософських наук, старша наукова співробітниця відділу логіки і методології науки Інституту філософії імені Г.С. Сковороди НАН України, 01601, Київ, вул. Трьохсвятительська, 4 nviatalia@gmail.com https://orcid.org/0000-0003-4839-1146

Присвячується пам'яті Анатолія Іимуратова

\section{ПАМ'ЯТЬ 3 ПОГЯЯДУ ЯОГІКИ І СЕМІОТИКИ}

Феномен пам'яті розглядається як компонент, імпліцитно присутній у процесі інформаційної комунікації. Наведено коротку типологію видів пам'яті, які утворюють референційне поле так званої семантичної пам'яті. Через підходи Ю. Лотмана та Р. Якобсона розглядається класичне уявлення про час, що тісно пов'язане з пам'яттю. Основна увага приділяється тому, як можна розглядати пам'ять у межах та за допомоги логіки. Як один зі шляхів розв'язання иього питання пропонується застосувати інструменти часової логіки через аналіз праць видатного українського логіка Анатолія Ішмуратова (1946-2017). Розглянуто класифікації часів О. Єсперсена, Г. Райхенбаха, В. Буля. Проаналізовано суб'єктивну й об'єктивну осі орієнтації, що лежкать в основі календарів, діаграм і шкал як фрагментів часу. На думку Іимуратова, ці інструменти - схеми, діаграми тощо - можна вважати мовами. Можлливість мовної об'єктивації значення визначає зв'язок логічного висновування, а отже, структурування семантичних царин, якими є спогади, засобами логічної мови та відповідно до ї̈ структур. Досліджуючи логічні та пізнавальні умови дії, Ішмуратов продовжував розвивати ідеї часової логіки та обгрунтовувати можливості їх застосування до пояснення психологічного сприйняття об'єктивного часу. Він будував схему семантичних зв'язків пам'яті як психологічного акту, що відтворює життєвий шлях особистості; він розрізняв спогади та «псевдоспогади», які разом впливають на переоцінку минулих подій, формують досвід особистості та ї̈ здатність конструювати альтернативи майбутнього. Особливе місце в дослідженнях Іимуратова займає його експлікація часової тризначної логіки та застосування часових модальностей до аналізу так званих перехідних станів. Подальше вивчення таких підходів могло б допомогти раціональному осмисленню пам'яті та дати цікаві результати.

Ключові слова: феномен пам'яті, семантична пам'ять, часова логіка, класифікація часів, осі орієнтації, «псевдопам'ять», досвід.

Цитування: Вяткіна, Н. (2021). Пам’ять з погляду логіки і семіотики. Філософська думка, 4, 142-152. https://doi.org/10.15407/fd2021.04.142 
Феномен пам'яті майже постійно перебуває у центрі уваги дослідників, але стабільно зберігає образ загадкового явища. Розглядатимемо пам'ять як один із компонентів, що імпліцитно присутній у процесі інформаційної комунікації 1 .

За змістом філософи розрізняють пам'ять як досвід (або персональну пам'ять), пропозиційну (або фактуальну) і практичну (або процедурну). У психології основний розподіл відбувається між декларативними (такими, що суб'єкт може вербалізувати) і недекларативними (які суб'єкт може тільки демонструвати, але не вербалізувати) видами пам'яті [Bernecker, 2009: pp.12-13]. I це тільки мала частина різновидів пам'яті. Нас переважно цікавитиме поділ декларативної пам'яті на семантичний та епізодичний види [Tulving, 1972].

Семантична пам'ять є здатністю, формою або ж місцем (якщо йдеться про нейропроцеси) зберігання загального знання про світ, поняття, правила і мову. Характерною особливістю семантичної пам'яті є те, що вона не обов'язково вимагає референції до подій. Епізодична ж пам'ять складається $з$ досвіду запам'ятовування, здатності повертатись і переживати заново події, що збереглися в пам'яті [Squire, Kandel, 1999: 106n].

3 проблематикою пам'яті тісно пов'язують класичне уявлення про час через співвідношення «минуле-теперішнє-майбутнє», що воно є термінологічною й поняттєвою віссю, вздовж якої розташовується майже вся перелічена вище група понять.

Роман Якобсон розглядає історію як діахронію, що не суперечить синхронії. (Вочевидь, у пам'яті саме так і відбувається: поєднання вертикалі та горизонталі подій, що в ній збереглися, а коли ми їх відтворюємо, події знов набувають щоразу нового характеру - залежно від сучасного перебігу подій, настрою, налаштованості, забарвлення, події міняються місцями, спливає щось нове, а щось занурюється знов на глибину). «...[І]сторія системи є своєю чергою система. Чистий синхронізм тепер виявляється ілюзією: кожна синхронічна система має своє минуле й майбутнє як невіддільні структурні елементи системи»; «кожна система наявна обов'язково як еволюція, а з іншого боку, еволюція має неуникненно системний характер» [Якобсон, 1999: с. 62]. Якобсон називає це явище «динамічною синхронією».

За Юрієм Лотманом, у культурі таке розташування за часом є наслідком лінійної організації тексту, з її «до» і «після», що саме й породжує концепцію лінійного часу, а також правило причинності, почуття історизму й інші уявлення, що стали основоположними для цілої низки типів культури [Лотман, 1992: c. 29].

Як можна аналізувати пам'ять в логіці? Передовсім зауважимо, що логіку не застосовують до філософських проблем у той самий спосіб, у який інженер застосовує певну техніку для обчислення напруги для мосту, - вона

\footnotetext{
${ }^{1}$ Цю статтю написано на основі розділу колективної монографії «Семіотичний аналіз явищ культури» як його продовження [Вяткіна, 2021: сс. 172-218].
} 
діє не таким прямим чином: логіка може пропонувати технічну мову з відносно точними значеннями як посилення філософського дискурсу й допомогу в точній комунікації; виявляючи аналогії між різними поняттями або проблемами, які раніше не спостерігалися, аналіз у логічній формі робить філософську аргументацію точнішою і допомагає будувати нові концептуальні рамки [van Benthem, 2007].

Пам'ять, знання, переконання, уява тощо розглядаються в логіці переважно як пропозиційні відношення, їх досліджує сучасна філософська логіка. Традиційно логіка мала справу з концептуальними побудовами статичного світу. Звичним було вважати висловлювання незмінно істинними або незмінно хибними. Але внаслідок досліджень понять, що стосуються людської дії, виникла потреба в логіці, яка б вивчала структуру динамічного світу [фон Вригт, 1986: сс. 513-538]. «У часовій логіці моделюються міркування, які змінюють своє істиннісне значення з плином часу. Істиннісне значення висловлювань розглядається відносно моментів або інтервалів тієї чи іншої часової структури. За допомогою часової структури в семантиці часової логіки репрезентується відповідний тип структури часу» [Навроцький, 2005: с. 103]

Отже, пам'ять і пов'язані з нею процеси запам'ятовування і згадування, а також похідні від них - свідчення можна аналізувати засобами часової логіки ${ }^{2,3}$ як процеси мислення у часі.

У дослідженні цієї проблематики неможливо оминути увагою доробок Анатолія Теміргалієвича Ішмуратова (1946-2017), визначного українського логіка, з яким ми разом працювали з 1975 року у відділі логіки наукового пізнання (так тоді називався відділ логіки і методології науки) Інституту філософії. Його кандидатська дисертація і перша монографія були присвячені аналізу логіки часу.

Розглянемо дослідження пам'яті, спогадів, опису подій засобами часової логіки, запропонованої Анатолієм Ішмуратовим, простеживши за його думкою. У праці «Логічні теорії часових контекстів» [Ишмуратов, 1981] він зауважує, що лінгвістичний аналіз зазвичай підготовляє «грунт» для аналізу логічного, і здебільшого результати саме лінгвістичного аналізу стають вихідним пунктом логічних досліджень. Власне, «виникнення часової логіки значною мірою зобов'язане дослідженням лінгвістами дієслівних форм, спробам класифікувати граматичні часи і способи їх вираження» [Там само: с. 15].

3 погляду логіки загальний напрям має такий вигляд: пам'ять можна аналізувати як мову або систему висловлювань, виражених мовою, коли сама мова розглядається як носій інформації, а вирази мови, або їі фрагменти оцінюються на «істинність-хибність». «... Якщо до умов оцінки виразу до-

\footnotetext{
2 До завдань цієї статті не входить детальний розгляд еволюції поняття часу, часової логіки та класичних праць з логіки часу, таких як дослідження Артура Н. Прайора (Arthur N. Prior «Past, Present and Future», 1967) та Г. фон Вригта.

3 огляду на характер цієї статті, авторка розглядає поняття «часова логіка» і «логіка часу» як тотожні.
} 
лучають часові характеристики, такий вираз називатимемо часовим контекстом...» [Там само: с. 5].

Класифікація часів Отто Єсперсена [Есперсен, 1958] є відправною побудовою для формування концепції часовоїлогіки Ішмуратова. Грунтуючись на системі часів з «Латинської граматики» Магдена, вельми відомої у ті часи, та критично її переробляючи, Єсперсен будує систему «сімох часів» $\mathrm{i}$ в межах цієї системи аналізує особливості вираження граматичних часів у природних мовах. Він формулює проблему: як можна визначити універсальну систему «часів»? 3 огляду на те, що англійській мові бракує, за його твердженням, «питомо (англосаксонських) слів» як для позначання природного часу, так і для граматичного часу, Єсперсен уводить розрізнення на past time «минулий час», past tense «форма минулого часу», present time «теперішній час», present tense «форма теперішнього часу», future time «майбутній час», future tense «форма майбутнього часу». Ішмуратов наводить повний перелік часів за Єсперсеном: «... головні підрозділи часу $(A-$ минуле, $B-$ теперішнє, $C$ - майбутнє) і підпорядковані підрозділи часу ( $A a-$ доминуле, $A b$ - те саме, що і $A, A c$ - післяминуле, $C a$ - домайбутнє, $C b$ - те саме, що й $C, C c-$ післямайбутнє). Головні підрозділи часу орієнтуються на теперішній момент $/ B /$, а підлеглі підрозділи часу - на якийсь момент у минулому $/ A b /$ або у майбутньому $/ C b /$. Усі часи можна розташувати вздовж однієї прямої, яка символізує часову вісь» [Ишмуратов, 1981: с. 16].

Уявімо горизонтальну лінію: додавши проміжні підрозділи часу, отримуємо схему, що в ній поняттєві терміни (природні підрозділи) розташовуються вище, а синтаксичні (граматичні) - нижче від лінії, що відображає плин часу [Есперсен, 1958: с. 243]

Однак Єсперсен самокритично зізнавався, що хоча «отримана у такий спосіб система видається невразливою з логічного погляду, ... вона не претендує на охоплення всіх можливих підрозділів часу і всіх часових форм, які реально існують у різних мовах. ...категорії часто перекривають одна одну, а терміни не завжди є вдалими» [Есперсен, 1958: с. 301].

Ішмуратов наводить іншу ідею систематизації дієслівних часів - схему Ганса Райхенбаха, який намагався представити речення з дієсловом у деякому граматичному часі як вираз без часового контексту, що виявилося неможливим через принципову нередуковуваність часових висловлювань до «позачасових». Але найбільш привабливими у контексті часової логіки виявляються дослідження онтологічних передумов аналізу дієслівних часів, які здійснював Вільям Буль [Bull, 1968] (прізвище наводимо у транскрипції А. Ішмуратова). Зазначають, що Буль так само розрізняв природний і граматичний часи [DeCarrico, 1986].

Для аналізу пам'яті має значення звернення Буля до онтології, до фізичних аспектів часу, розрізнення ним суб'єктного й об'єктного часів. Суб'єктний час він визначав як такий, що оцінюється суб'єктом, його внутрішніми подіями, серед яких ми знаходимо спогади, пам'ятні події. Об'єктний час - 
це час, що вимірюється періодичністю природних явищ. Виразна ілюстрація: «Якщо, наприклад, дружина заявляє чоловікові: “Обід буде готовий за хвилину”, то значення цієї “хвилини” далеко не те саме, що у виразі “Період напіврозпаду елемента $A$ дорівнює одній хвилині”. Буль відмічає, що слова, які виражають суб’єктивну оцінку, є щось подібне до $x, y, z$ у математичних формулах, тобто вони виконують роль часових змінних - символів, що замішують деяку визначену величину. Наприклад, “незабаром”, “одразу”, “задовго до”» [Ишмуратов, 1981: с. 17].

Ішмуратов виокремлює з досліджень Буля «суб’єктні й об’єктні осі орієнтації», які визначають ті чи інші події як точки співвіднесення й констеляції всіх інших подій. Це «особливий пункт, місце в океані часу, з якого ми оглядаємо всесвіт або як минуле, або як теперішнє, або як майбутнє» [Там само]. Об’єктні осі орієнтації утворюють природні, космічні події: схід сонця, фази місяця, пори року. Деякі події можуть виявитися знаковими для певних культур, народів, історичних епох, що стають віхами в колективній історичній пам'яті. Можемо доповнити думку Буля, згадавши Комету Галея, яка стала прообразом Віфлеємської зірки і знаком чималої кількості історичних подій, глобальних і локальних. Як зазначає Ішмуратов, вираз «до громадянської війни» має різні конотації для росіянина і для американця. 3 огляду на українську історію ми б додали особливу конотацію для українця щодо цього часового маркера. Ще менш «об'єктними» є осі орієнтації для окремої родини, коли йдеться про історію весіль, народження дітей, різних пам'ятних подій. Об'єктивні події, що стосуються орієнтації в часі окремої людини, утворюють об’єктну вісь орієнтації. Але найважливіші осі орієнтації, які підкреслює Ішмуратов у дослідженні Буля, що є важливими для дослідження пам'яті, - це «події, які відбуваються всередині людини: акт мовлення, споглядання, слухання, відчування, спогади, передбачення тощо. Тільки одна 3 подій, що відбуваються всередині людей, є об’єктною віссю орієнтації. Акт мовлення - єдина “суб'єктна” подія, яка може бути помічена і використана іншим індивідом. Вона функціонує, отже, як вісь орієнтації для мовця і для того, хто сприймає мовлення. Ця вісь ... є основним пунктом орієнтації для всіх часових систем» [Ишмуратов, 1981: с. 18]. Тут можемо провести паралель із феноменологією, з ії «головною методологічною настановою, яку реалізує Гусерль у дослідженні феномена часу - виключення часу об’єктивного світу», що походить від вчення Брентано [Кебуладзе, 2005: с. 65] ${ }^{4}$.

Ішмуратов описує структуру мовленнєвої осі орієнтації, стосовно якої тільки й можливо, на його думку, говорити про минуле, теперішнє та майбутнє. На цій осі відзначається те, що мовець згадує - минуле, що мовець передбачає - майбутнє; розрізняється «точкове теперішнє» $\mathrm{i}$ «протяжне теперішнє». Його цитата з Буля: «Протяжне теперішнє є, очевидно, часовим

\footnotetext{
4 Можемо припустити, що захоплення суб’єктивним виміром переживання часу висвітлює інтерес Анатолія Ішмуратова до феноменології, який зрештою проявився в одній із його останніх праць, присвяченій феноменології з логічного погляду.
} 
інтервалом між деякою подією $A$, що пригадується, і подією $A^{\prime}$, що передбачається; точкове теперішнє є актом встановлення відношення порядку, яке визначає часовий інтервал» [Ишмуратов, 1981: с. 18]. На думку Буля, протяжне теперішнє є абстракцією. Ми говоримо про «нинішній момент», «нинішнє століття», але справжнім теперішнім буде точкове теперішнє, яке збігається з віссю орієнтації.

«Осі орієнтації служать основою побудови об'єктних і суб'єктних календарів. У випадку, якщо календар починає свій відлік від Різдва Христового, це - об'єктний календар, якщо точкою відліку є якась персональна подія або помітка, що має значення тільки в окремій мовленнєвій ситуації, «нині», «цей час», - суб’єктний календар. На думку Буля, за структурою ці календарі не відрізняються і базуються на чотирьох принципах: (1) використання імені, яким позначають часовий інтервал (день, місяць тощо); (2) осі орієнтації; (3) три відношення порядку стосовно осі орієнтації і (4) позиції кожного часового інтервалу, що утворюють вісь орієнтації. Буль це описує так, як нібито вісь суб'єктного календаря «ковзає» вздовж осі об'єктного календаря й набуває дедалі нових значень стосовно нього. Об’єктний календар не дає можливості визначати його частини як минуле, теперішнє й майбутнє. І в цьому сенсі вісь орієнтації об’єктного календаря дає нам тільки умовне теперішне, тоді як суб'єктна вісь календаря створює актуальне теперішне [Там само: с. 19].

У ширшому розумінні, календарі є окремим випадком діаграм і шкал часу (timelines) як фрагментів часу, що мають лінійне зображення. Їх використовують і звичайні люди, і професіонали. Їх розглядають двояко: як наочну експозицію даних після того, як історики виконали свою роботу, та як невіддільний складник історичного дослідження. Ці діаграми та часові рамки є або принаймні мають бути невіддільною частиною того, як ми пізнаємо минуле. Як і будь-які часові схематичні зображення, ці шкали унаочнюють послідовність подій у часі, структурують і відображають віртуальне середовище й мають неабиякий умовивідний потенціал (inferential potential) [Champagne, 2016]. Саме це спонукало Чарлза Пірса сказати, що «відмітною властивістю ікони (іконічного знаку. - H.B.) є те, що шляхом безпосереднього спостереження за нею можна виявити інші істини щодо іiі предмета, крім тих, яких достатньо для визначення іiї конструкції» [Peirce, 1931-1935: vol. 2, p. 279]. Пірс визначав діаграму як знаковий механізм, відношення якого нагадують відношення його об'єкта [Там само, p. 277].

Сучасне використання діаграм як часових і просторових схем утворює особливу сферу досліджень, творчості і є ознакою якості сучасних освітніх технологій, перетворюючись на розумові мапи (mind maps), утворені з безлічі локалізацій - ліній, перетинів, гілок тощо. Ці лінії часу, вузли й точки на лінії, схеми й діаграми подій у спогадах чи історичних описах поряд зі знаками (які своєю чергою є знаками чогось, знаками значень) $є$ формами існування референтів (не реальних об’єктів і подій - це той випадок, що ілюструє 
відмінність і незбіжність референції і значення). Кожне поєднання знаків та їхніх референтів у певних точках локалізації на діаграмах породжує відповідну інтерпретацію. Якщо ці лінгвістичні знаки роз'єднаються - це буде інша ситуація, що потягне за собою відмову від деяких висновків. Головна зручність створення діаграм і мап - це можливість об'єднання різноманітних історичних фактів і подій у єдиному полі усвідомлення [Pietarinen, 2014: p. 301].

3 позицій логіки, як зазначає Ішмуратов, схеми, діаграми, таблиці, рисунки, креслення можна вважати мовами. Від можливості мовної об’єктивації смислу, від точності опису смислу виразу тією чи іншою мовою залежить ефективність аналізу смислу виразу, що на його основі визначається відношення логічного слідування. Те, що ми бачимо на діаграмах, є результатом спрощення, схематизації смислового аспекту природної мови, а також структурування смислової царини засобами логічної мови та відповідно до ії структур [Ишмуратов, 1981].

Діаграми, часові схеми є своєрідними містками, що поєднують логіку і семіотику, перетворюючись на знаково-символічні системи, породжуючи нові інтерпретації, створюючи нові структури - особливу «реальність» між мовою (мовленням, текстом) і реальністю. Ця особлива «реальність» стосовно часового контексту, яка складається з порівнюваних між собою подій, є часовим потоком. Те, що ми гіпотетично припускаємо стосовно минулого або майбутнього, можна виразити як особливий часовий потік, а саме можливий світ. Як стверджує Ішмуратов: «У загальному випадку можливим світом можна вважати зміст будь-якого психічного акту (нині ми сказали б «ментального акту». - H.B.): спогаду, передбачення, уявлення, уяви тощо.

Кінофільм, наприклад, можна вважати запрограмованим часовим потоком уявлень. "Розшарування" реальності, авжеж, є умовним (тією ж мірою, що й умовним є розрізнення метамовних рівнів у мові або рівнів рефлексії в акті мислення), однак у багатьох відношеннях є корисним» [Там само: с. 14].

Найважливішою у розробці Вільяма Буля виявилася «гіпотетична часова система», яка перевершила систему часів Єсперсена вкупі з ідеями Райхенбаха, що в ній він поєднав структуру часу з мовленнєвими семантиками. Для нас у тексті Буля вкрай цінним $є$ його висновок, що його особливо підкреслює Ішмуратов: автор попереджає читача, що ця гіпотеза «може застосовуватися тільки до тих культур, які мають абстрактне поняття часу і користуються поняттям часового інтервалу» [Там само: с. 21].

Досліджуючи логіко-когнітивні умови дії, Ішмуратов вдається до застосувань ідей логіки часу щодо пояснення об'єктивного часу, як він когнітивно дається суб'єктові з погляду його суб'єктивного часу і на підставі його «когнітивної онтології» ${ }^{5}$. Застосовуючи часові оператори та індикатори часу,

\footnotetext{
$\overline{5}$ На це дослідження Ішмуратова надихнула знаменита свого часу монографія про психологічний час особистості [Головаха, Кроник, 1984].
} 
він фіксує інтервал, що мав би містити зміст спогадів. «Дієсловом “згадує” оцінюється не пам'ять - “сховище” суб’єкта, а фіксується ментальний акт мисль, уявлення, образ, що мав раніше статус “теперішньої” когнітивної події і є у даному теперішньому змістом ментального акту, що фіксується» [Ишмуратов, 1987: с. 39]. Виявляється, що згадувати можна лише події одного-єдиного перебігу подій - власного життєвого шляху суб'єкта. Решта альтернатив минулого («як би було інакше»), на думку Ішмуратова, не є спогадами. «Контрфактичне в минулому можна розглядати як альтернативне майбутнє відносно деякого більш минулого моменту (дієслівний час “майбутнього в минулому”)» [Там само]. Утім, такі «псевдоспогади» суттєво впливають на переоцінку минулих подій і вибору, який було зроблено в минулому, що, своєю чергою, формує досвід суб’єкта і його здатність до конструювання альтернатив майбутнього та міркувань щодо нього.

Окреме місце у доробку Ішмуратова посідає його експлікація часової тризначної логіки, що має застосування до опису так званих перехідних станів, а також припущень часової логіки шодо мінливості істиннісного значення за цих переходів. Останнє з очевидністю вимагає припущення про існування третього істиннісного значення - «не мати значення». Але це виходить за межі цієї статті і є предметом подальшого спеціального дослідження.

Свідчення, на які спираються історики, зазнають впливу всіх вад, притаманних пам'яті. Події постійно переписуються й упорядковуються, а також переоцінюються у світлі пізнішої інформації, якої очевидці подій могли й не знати. Можливо, це відбувається тому, що історичне значення подій пов'язане з позаісторичним значенням, а останнє може змінюватися залежно від людських уподобань та інтересів. Засоби часової логіки дають інструменти для істиннісного оцінювання свідчень і структурування інформації, що фіксується пам'яттю, переводячи ії зі сфери відчуттів і переживань до сфери раціонального спостереження.

Зрозуміло, що цей огляд торкнувся лише невеликої частини того, що залишив по собі Анатолій Ішмуратов. Творчий спадок вченого чекає на нових небайдужих дослідників, готових розвинути його задуми.

\section{ДЖЕРЕЛА}

Вяткіна, Н.Б. (2021). Референційні механізми деконструкції культурних кодів, досвіду і пам'яті з погляду логіки і семіотики. В: Семіотичний аналіз явищ, культури: Монографія (розд. V, сс.172-218). Київ: Інститут філософії імені Г.С. Сковороди НАН України.

Головаха, Е.И., Кроник, А.А. (1984). Психологическое время личности. Киев: Наукова думка.

Есперсен, О. (1958). Философия грамматики. Москва: Издательство иностранной литературы.

Ишмуратов, А.Т. (1981) Логические теории временных контекстов (временная логика). Киев: Наукова думка.

Ишмуратов, А.Т. (1987). Логический анализ практических рассуждений. Київ: Наукова думка. 
Ішмуратов, А.Т. (1997) Вступ до філософської логіки. Київ: Абрис.

Кебуладзе, В. (2005). Феноменологія. Навчальний посібник. Київ: ППС.

Лотман, Ю.М. (1992). Мозг - текст - культура - искусственный интеллект. Статьи по семиотике и типологии культуры в трех томах (т. I, сc. 25-34). Таллинн: Александра.

Навроцький, В.В. (2005). Логіка соціальної взаємодії. Харків: Консум.

фон Вригт, Г.Х. (1986). Логико-философские исследования. Москва: Прогресс.

Якобсон, Р. (1999). Юрий Тынянов в Праге. Роман Якобсон. Тексты, документы, исследования. Москва.

Bernecker, S. (2009). Memory: A Philosophical Study. Oxford: Oxford University Press.

Bull, W. E. (1968). Time, Tense and the Verb. Berkeley, Los Angeles: University California Press.

Champagne, M. (2016). Diagrams of the Past: How timelines can aid the growth of historica knowledge. Cognitive Semiotics, 9(1), 11-44.

DeCarrico, J. S. (1986). Tense, Aspect, and Time in the English Modality System. TESOL Quarterly, 20(4), 665-682.

Peirce, C.S. (1931-1935). CP: Collected Papers of Charles Sanders Peirce (Eds.: Ch. Hartshorne, P. Weiss, A. Burks), Vols. I-VI. Cambridge, MA: Harvard University Press.

Pietarinen, A.-V. (2014). Natural propositions naturalized. Cognitive Semiotics, 7(2), 297-303.

Scragg, G. (1978). Semantic Nets as Memory Methods. In: E. Charniak, Y. Wilks (Eds.), Computational Semantics (pp.101-128). Amsterdam etc.

Squire, L.R., Kandel, E. (1999). Memory: From Mind to Molecules. New York: Scientific American Library.

Tulving, E. (1972). Episodic and Semantic Memory. In: E. Tulving, W. Donaldson (Eds.), Organization of Memory (pp. 382-404). New York: Academic Press.

van Benthem, J. (2007). Logic, Rational Agency, and Intelligent Interaction. In: Proceedings Beijing 2007 DLMPS Conference. S.1.

Отримано 26.10.2021

\section{REFERENCES}

Bernecker, S. (2009). Memory: A Philosophical Study. Oxford: Oxford University Press.

Bull, W. E. (1968). Time, Tense and the Verb. Berkeley, Los Angeles: University California Press.

Champagne, M. (2016). Diagrams of the Past: How timelines can aid the growth of historical knowledge. Cognitive Semiotics, 9(1), 11-44.

DeCarrico, J. S. (1986). Tense, Aspect, and Time in the English Modality System. TESOL Quarterly, 20(4), 665-682.

Golovakha, Ye.I., Kronik, A.A. (1984). Psychological time of personality. [In Russian]. Kyiv: Naukova Dumka. [= Головаха 1984]

Ishmuratov, A.T. (1981). Logical Theories of Temporal Contexts (Tense Logics). [In Russian]. Kyiv: Naukova Dumka. [= Ишмуратов 1981].

Ishmuratov, A.T. (1987). Logical Analysis of Practical Reasoning. [In Russian]. Kyiv: Naukova Dumka. [= Ишмуратов 1987]

Ishmuratov, A.T. (1997). Introduction to Philosophical Logic. [In Ukrainian]. Kyiv: Abrys. [= Ішмуратов 1997]

Jacobson, R. (1999). Yurii Tynianov in Prague. Texts, documents, investigations. [In Russian]. Moscow. [= Якобсон 1999].

Jespersen, O. (1958). The Philosophy of Grammar. [In Russian]. Moscow: Publishing House of Foreign Literature. [= Есперсен 1958].

Kebuladze, V. (2005). Phenomenology. Tutorial. [In Ukrainian]. Kyiv: PPS. [= Кебуладзе 2005]. Lotman, Yu.M. (1992). Brain - Text - Culture - Artificial Intelligence. Articles on Semiotics and Typology of Culture (vol. I, pp. 25-34). [In Russian] Tallinn: Aleksandra. [= Лотман 1992]. 
Navrotskyi, V. (2005). The logic of social interaction. [In Ukrainian]. Kharkiv: Consum. [= Навроцький 2005].

Peirce, C.S. (1931-1935). CP: Collected Papers of Charles Sanders Peirce (Eds.: Ch. Hartshorne, P. Weiss, A. Burks), Vols. I-VI. Cambridge, MA: Harvard University Press.

Pietarinen, A.-V. (2014). Natural propositions naturalized. Cognitive Semiotics, 7(2), 297-303.

Scragg, G. (1978). Semantic Nets as Memory Methods. In: E. Charniak, Y. Wilks (Eds.), Computational Semantics (pp.101-128). Amsterdam etc.

Squire, L.R., Kandel, E. (1999). Memory: From Mind to Molecules. New York: Scientific American Library.

Tulving, E. (1972). Episodic and Semantic Memory. In: E. Tulving, W. Donaldson (Eds.), Organization of Memory (pp. 382-404). New York: Academic Press.

van Benthem, J. (2007). Logic, Rational Agency, and Intelligent Interaction. In: Proceedings Beijing 2007 DLMPS Conference. S.1.

Viatkina, N.B. (2021). Reference mechanisms for the deconstruction of cultural codes, experience, and memory in terms of logic and semiotics. [In Ukrainian]. In: Semiotic analysis of cultural phenomena. Monograph (ch. V, pp.172-218).. Kyiv: H.S. Skovoroda Institute of Philosophy, National Academy of Sciences of Ukraine. Retrieved from: https://www.filosof.com.ua. Biblioteka.html [= Вяткіна 2021]

von Wright, G.H. (1986). Explanation and Understanding. [In Russian]. Moscow: Progress. [= фон Вригт 1986].

Received 26.10.2021

Nataliia Viatkina, Candidate of Sciences in Logic,

Senior Research Fellow at the Department of Logic and Methodology of Science,

H.S. Skovoroda Institute of Philosophy,

National Academy of Sciences of Ukraine,

4, Triokhsviatytelska St., Kyiv, 01601

nviatalia@gmail.com

https://orcid.org/0000-0003-4839-1146

\section{MEMORY IN TERMS OF LOGIC AND SEMIOTICS}

The phenomenon of memory is considered as a component implicitly present in the process of information communication. A short typology of memory kinds that form a referential field around so-called semantic memory is given. Through the approaches of Yu. Lotman and R. Jacobson, the classical notion of time is considered through the relationship "Past-Present-Future", which is closely related to the problems of memory. The focus is on how could the memory be considered within logic and by means of logic? As one of the ways of solving the point, to apply the tools of tense logic to the problem through the analysis of the works of Anatoly Ishmuratov (1946-2017), a prominent Ukrainian logician, is proposed. The classifications of the tenses by O. Jespersen, H. Reichenbach, W. Bull are considered. The subjective and objective axes of orientation, which form the basis of calendars, charts and scales, as fragments of time, are analyzed. According to Ishmuratov, these instruments - schemes, diagrams, etc. can be considered languages. The possibility of language objectification of meaning determines the relationship of logical inference, and thus the structuring of semantic areas, which are memories, by means the language of logic and in accordance with its structures. Through the study of logical and cognitive conditions of action, A. Ishmuratov continued to develop ideas of tense logic and their application to explain the psychological perception of objective time. He construed a scheme of semantic connections of memory as a mental act that reproduces the life path of the individual; he distinguished between memories and "pseudo-memories", which together influence the 
reassessment of past events, shape the individual's experience and his ability to construe alternatives to the future and reasoning about it. A special place in A. Ishmuratov's research is occupied by his explication of temporal three-valued logic and application of temporal modalities to the analysis of so-called transient states. Further study of such approaches could help to make sense of rational explication of memory, testimonies, reminiscences of past events and give interesting results.

Keywords: memory phenomenon, semantic memory, temporal logic, time/tense classification, orientation axis, "pseudo-memory", experience. 